\title{
Correction: oral ponesimod in relapsing-remitting multiple sclerosis: a randomised phase II trial
}

Olsson T, Boster A, Fernández Ó, et al. Oral ponesimod in relapsing-remitting multiple sclerosis: a randomised phase II trial. J Neurol Neurosurg Psychiatry 2014;85:1198-1208.

For Figure 3 (A), the 95\% CI values provided for the 3 Ponesimod groups below each percent (e.g., $10 \mathrm{mg}$ shows $43 \%(0.34-0.95)$ ) are not correct as the CI intervals belong to the treatment effect [ratio] and not percentage reduction. Instead, for Figure 3 (A), the graph should indicate the following: $10 \mathrm{mg}$ : 43\% (95\% CI: 4.8-66.3), $20 \mathrm{mg}$ : 83\% (95\% CI: 71.190.0), and 40mg: 77\% (95\% CI: 61.6-86.7).

Figure legend should read as follows:

\section{A}

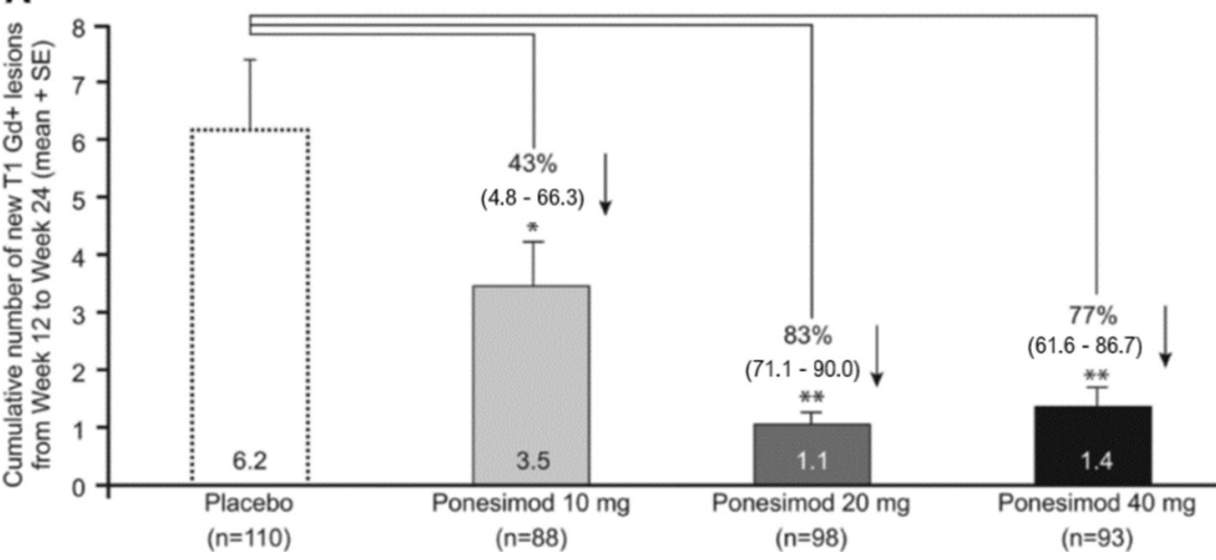

Figure 3 (A) Cumulative number of new $\mathrm{T} 1 \mathrm{Gd}$ +lesions detected by magnetic resonance image scanning at weeks 12-24 (per-protocol analysis set). Graph shows mean+SE.SE The percentage reduction (95\% Cl) vs placebo is shown for each ponesimod treatment group. (B) Dose-response analysis for the cumulative number of new $T 1 \mathrm{Gd}$ +lesions from week 12 to 24 (per-protocol analysis set). Black dots represent the mean value for each dose and grey dots represent the fitted models obtained in the bootstrap process. ${ }^{*} p<0.05$; ${ }^{* *} p<0.0001$. T1 Gd+, T1-weighted gadolinium-enhanced.

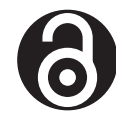

\section{OPEN ACCESS}

Open access This is an open access article distributed in accordance with the Creative Commons Attribution Non Commercial (CC BY-NC 4.0) license, which permits others to distribute, remix, adapt, build upon this work non-commercially, and license their derivative works on different terms, provided the original work is properly cited, appropriate credit is given, any changes made indicated, and the use is non-commercial. See: http://creativecommons.org/licenses/by-nc/4.0/.

(C) Author(s) (or their employer(s)) 2019. Re-use permitted under CC BY-NC. No commercial re-use. See rights and permissions. Published by BMJ.

J Neurol Neurosurg Psychiatry 2019;90:e7. doi:10.1136/jnnp-2013-307282corr1

A Check for updates 